\title{
Problems of Ensuring Personnel Stability and Security in the Government Authorities of Countries with Economies in Transition
}

\author{
SVITLANA V. KAPITANETS ${ }^{1}$, NATALIIA VARENIA ${ }^{2}$, OLENA L. KOROLCHUK ${ }^{3}$, TETIANA \\ KULINICH $^{4}$, OLENA KILNITSKA ${ }^{5}$, HANNA HOLOVCHAK ${ }^{6}$ \\ ${ }^{1}$ Department for the Improvement of Counteraction to Customs Offenses, University of State Fiscal \\ Service of Ukraine, Irpin, UKRAINE \\ ${ }^{2}$ Scientific and organizational center, National Academy of Security Service of Ukraine, Kyiv, \\ UKRAINE \\ ${ }^{3}$ Department of Social and Humanitarian Policy, National Academy for Public Administration under \\ the President of Ukraine, Kyiv, UKRAINE \\ ${ }^{4}$ Department of Organizational Management, Lviv Polytechnic National University, Lviv, UKRAINE \\ ${ }^{5}$ Department of Economics and Entrepreneurship, Polissia National University, Zhytomyr, UKRAINE \\ ${ }^{6}$ Department of Accounting and Auditing, Ivan Franko Lviv National University, Lviv, \\ UKRAINE
}

\begin{abstract}
The goal of the article was to investigate the problems of personnel security in the government authorities of countries with a transition economy. Personnel security has been considered from the position of a bureaucratic approach, which makes it impossible for government authorities' personnel policy to be effective and the development of professionalism and democracy. Theories of human resource management and management theory have been defined as general concepts of ensuring personnel security. The connection between the quality of government authorities' regulatory capacities and the efficiency of the government of transition economy has been revealed; the link between controlling corruption and increasing the efficiency of the government of transition economy has been established.
\end{abstract}

Key-Words: - Personnel Security, Government Personnel Policy, Transition Economy, Government Authorities, Anti-Terrorist Security, Information Security, Legal Awareness, Postgraduate Studies.

Received: October 10, 2020. Revised: May 3, 2021. Accepted: May 12, 2021. Published: May 20, 2021.

\section{Introduction}

Ensuring personnel security in the government authorities is a narrow subject of research, in particular in countries with transition economy. In the literature of recent years, little attention has been devoted to the issues of personnel security in government authorities, which determines the relevance and need to eliminate the existing gap. The development of e-government concept, the integration of information technology, the need to protect personal data are the factors that reinforce personnel security problems [1]. The global democracy's theory and concept of F. Fukuyama, which is the source of e-democracy development [2], appropriate and global governance, New Public Managemnet [3] toughen the requirements for personnel management in government authorities for employees. Accordingly, the problems arising from the development of government management concepts are intensified.

\section{Literature Review}

The investigation of personnel security in government authorities is limited to theories of public administration efficiency and has not become widespread. Personnel security in the system of public administration should be considered as a set of mechanisms, principles, methods aimed at the formation, development and preservation of human resources of the public administration system [4]. In the narrow sense, personnel security means the protection of personnel, ensuring the development, selfrealization and self-improvement of employees. In an extended sense, personnel security is a set of mechanisms, methods, techniques that ensure the protection and effectiveness of public administration from threats of destructive professionalism, unprofessionalism, increasing the 
number of people who have personal or corrupt ties to obtain their own benefits, etc.

Threats to personnel security in the public administration system are divided depending on the possibility of forecasting: predictable or unpredictable; depending on the security object: personnel, technologies, information, technical equipment, image; depending on the field of origin: external and internal [4]. Corruption is a type of threat to personnel security in the public administration system, which should be considered as the use of a person's official powers and related opportunities in order to obtain an illegal benefit or to accept a promise / offer of such a benefit for himself or others or, accordingly, a promise / offer or provision of improper advantage to a person or, at his request, to other individuals or legal entities in order to persuade that person to misuse the powers conferred on him and the related opportunities. Some relevant studies can be found in [5] and [6].

A qualitative approach to personnel management and the traditional, more bureaucratic approach [7], which is characteristic for transition economies, determine the level of personnel security. Traditional theories of human resource management are used in government authorities. "The information revolution including computer-assisted staffing and selection, automated customer service, and virtual office have not become significantly important to respondents" [8]. The concept of secure management control on a global scale is integrated into the concept of e-government [9]. Personnel policy is determined by the level of corruption, which in transition economies is an obstacle to effective administrating and democracy $[10 ; 11$. The development of the regulatory framework for corruption regulation and control is a prerequisite for effective personnel policy, professionalism of government authorities, as a consequence - a high level of personnel security [12].

\section{Data and Methodology}

The research is based on theories of human resources' management in government authorities and theories of public administration, which make it possible to form new knowledge about the integration of management control concepts into the practice of human resources' management.

The analysis has been conducted for countries with a transition economy according to panel data from the World Bank and Worldwide Governance Indicators (WGI) for the period of 2008-2018. The selected indicators have mostly reflected the level of personnel security, characterized the effectiveness of personnel policy in public administration and made it possible to identify the level of implementation of management control. Based on panel data from 12 countries with transition economies for the period of 1996-2018, models for estimating the relationship between variables were created in order to identify cause-effect relations between personnel security and government efficiency.

\section{Results}

The transition to market economic conditions is carried out through the transformation of institutions that determine the effectiveness of personnel policy and personnel security, and therefore - of the government authorities. During 2008-2018, the efficiency of the government authorities increased significantly in Albania, Azerbaijan, Belarus, Kazakhstan, Moldova and Ukraine. Minor changes have taken place in Armenia, Georgia, the Kyrgyz Republic, Russia and Serbia. Such trends are a consequence of the personnel policy of the government authorities in transition economies. Hence, it is possible to identify internal and external problems of personnel security: the prerequisites for the formation, namely the quality of institutions and the quality of administrative staff responsible for human resource management; political pressure (see Table 1) [13].

Table 1. Government Effectiveness* in transition economies in 2008-2018

\begin{tabular}{|l|c|c|c|c|c|c|c|c|}
\hline Government Effectivness & \multicolumn{3}{|c|}{2008} & \multicolumn{3}{c|}{2018} & \multicolumn{3}{c|}{ Change } \\
\hline Country/Territory & Estimate & StdErr & Rank & Estimate & StdErr & Rank & Estimate & Rank \\
\hline Albania & $-0,36$ & 0,21 & 44,17 & 0,11 & 0,23 & 57,69 & 0,47 & 13,52 \\
\hline Armenia & $-0,17$ & 0,20 & 49,03 & $-0,02$ & 0,21 & 51,44 & 0,15 & 2,41 \\
\hline Azerbaijan & $-0,77$ & 0,21 & 22,82 & $-0,10$ & 0,22 & 49,04 & 0,67 & 26,22 \\
\hline Bosnia and Herzegovina & $-0,60$ & 0,23 & 33,50 & $-0,62$ & 0,22 & 28,37 & $-0,02$ & $-5,13$ \\
\hline Belarus & $-1,11$ & 0,24 & 12,62 & $-0,30$ & 0,23 & 40,38 & 0,81 & 27,76 \\
\hline Georgia & 0,30 & 0,22 & 65,53 & 0,61 & 0,22 & 74,04 & 0,32 & 8,50 \\
\hline Kazakhstan & $-0,46$ & 0,20 & 39,81 & 0,02 & 0,20 & 54,33 & 0,48 & 14,52 \\
\hline Kyrgyz Republic & $-0,79$ & 0,22 & 21,84 & $-0,61$ & 0,23 & 28,85 & 0,18 & 7,00 \\
\hline Moldova & $-0,77$ & 0,21 & 23,30 & $-0,47$ & 0,21 & 35,58 & 0,31 & 12,28 \\
\hline
\end{tabular}




\begin{tabular}{|l|c|c|c|c|c|c|c|c|} 
The Russian Federation & $-0,36$ & 0,20 & 43,69 & $-0,06$ & 0,21 & 50,96 & 0,30 & 7,27 \\
\hline Ukraine & $-0,72$ & 0,20 & 27,18 & $-0,42$ & 0,20 & 38,46 & 0,30 & 11,28 \\
\hline Serbia & $-0,19$ & 0,22 & 47,57 & 0,11 & 0,23 & 56,73 & 0,30 & 9,16 \\
\hline
\end{tabular}

* Reflects perceptions of the quality of public services, the quality of the civil service and the degree of its independence from political pressures, the quality of policy formulation and implementation, and the credibility of the government's commitment to such policies.

The quality of government's regulatory capabilities is a prerequisite for effective personnel policy and personnel security based on regulations. Data on Regulatory Quality in transition economies (see Table 2) indicate positive developments in Belarus, Georgia, Kazakhstan, Ukraine and Serbia.
The capability of authorities to develop and implement personnel policies is a prerequisite for personnel security. According to the Regulatory Quality indicator, transition economies are at the average level (minimum rating value - 25,96, Belarus, maximum rating value $-83,17$, Georgia).

Table 2. Regulatory Quality* in transition economies in 2008-2018

\begin{tabular}{|l|c|c|c|c|c|c|c|c|}
\hline Regulatory Quality & \multicolumn{3}{|c|}{2008} & \multicolumn{3}{c|}{2018} & \multicolumn{2}{c|}{ Change } \\
\hline Country/Territory & Estimate & StdErr & Rank & Estimate & StdErr & Rank & Estimate & Rank \\
\hline Albania & 0,15 & 0,18 & 55,83 & 0,28 & 0,21 & 63,46 & 0,13 & 7,64 \\
\hline Armenia & 0,34 & 0,17 & 62,14 & 0,27 & 0,19 & 62,50 & $-0,07$ & 0,36 \\
\hline Azerbaijan & $-0,35$ & 0,18 & 41,26 & $-0,38$ & 0,22 & 37,02 & $-0,03$ & $-4,24$ \\
\hline Bosnia and Herzegovina & $-0,15$ & 0,18 & 51,46 & $-0,21$ & 0,19 & 45,19 & $-0,06$ & $-6,26$ \\
\hline Belarus & $-1,24$ & 0,19 & 9,22 & $-0,66$ & 0,19 & 25,96 & 0,58 & 16,74 \\
\hline Georgia & 0,48 & 0,17 & 64,56 & 1,12 & 0,19 & 83,17 & 0,64 & 18,61 \\
\hline Kazakhstan & $-0,34$ & 0,17 & 43,20 & 0,14 & 0,18 & 60,10 & 0,48 & 16,89 \\
\hline Kyrgyz Republic & $-0,35$ & 0,17 & 42,23 & $-0,35$ & 0,19 & 37,98 & 0,00 & $-4,25$ \\
\hline Moldova & $-0,18$ & 0,18 & 50,00 & $-0,05$ & 0,18 & 51,92 & 0,13 & 1,92 \\
\hline The Russian Federation & $-0,39$ & 0,18 & 39,81 & $-0,54$ & 0,20 & 31,73 & $-0,15$ & $-8,08$ \\
\hline Ukraine & $-0,53$ & 0,18 & 33,01 & $-0,22$ & 0,18 & 44,23 & 0,31 & 11,22 \\
\hline Serbia & $-0,29$ & 0,19 & 45,63 & 0,01 & 0,21 & 56,25 & 0,30 & 10,62 \\
\hline
\end{tabular}

*Reflects perceptions of the ability of the government to formulate and implement sound policies and regulations that permit and promote private sector development.

The degree to which public authorities benefit in transition economies determines personnel security: decrease is possible in the level of professionalism of the government authorities as well as the effectiveness of decisions and the benefits of decisions for business, community. According to the
Control of Corruption indicator, transition economies are characterized by an average level of solution to this problem because the government authorities abuse their position for gaining benefit. So in this context personnel security is indirectly determined by this factor.

Table 3. Control of Corruption* in transition economies in 2008-2018

\begin{tabular}{|l|c|c|c|c|c|c|c|c|}
\hline Control of Corruption & \multicolumn{3}{|c|}{2008} & \multicolumn{3}{c|}{2018} & \multicolumn{3}{c|}{ Change } \\
\hline Country/Territory & Estimate & StdErr & Rank & Estimate & StdErr & Rank & Estimate & Rank \\
\hline Albania & $-0,59$ & 0,14 & 33,50 & $-0,52$ & 0,14 & 35,10 & 0,07 & 1,60 \\
\hline Armenia & $-0,71$ & 0,14 & 27,67 & $-0,35$ & 0,14 & 42,79 & 0,36 & 15,12 \\
\hline Azerbaijan & $-1,15$ & 0,14 & 11,17 & $-0,83$ & 0,14 & 21,63 & 0,32 & 10,47 \\
\hline Bosnia and Herzegovina & $-0,36$ & 0,14 & 42,72 & $-0,57$ & 0,14 & 31,73 & $-0,21$ & $-10,99$ \\
\hline Belarus & $-0,63$ & 0,15 & 32,04 & $-0,19$ & 0,14 & 49,04 & 0,44 & 17,00 \\
\hline Georgia & $-0,11$ & 0,14 & 54,37 & 0,71 & 0,14 & 76,44 & 0,82 & 22,07 \\
\hline Kazakhstan & $-0,98$ & 0,12 & 16,02 & $-0,50$ & 0,13 & 36,06 & 0,48 & 20,04 \\
\hline Kyrgyz Republic & $-1,22$ & 0,14 & 6,31 & $-0,95$ & 0,14 & 16,35 & 0,27 & 10,04 \\
\hline Moldova & $-0,63$ & 0,14 & 31,55 & $-0,73$ & 0,13 & 25,96 & $-0,10$ & $-5,59$ \\
\hline The Russian Federation & $-1,11$ & 0,13 & 12,14 & $-0,85$ & 0,13 & 21,15 & 0,27 & 9,02 \\
\hline Ukraine & $-0,84$ & 0,13 & 19,90 & $-0,87$ & 0,13 & 18,27 & $-0,04$ & $-1,63$ \\
\hline Serbia & $-0,31$ & 0,14 & 46,60 & $-0,37$ & 0,14 & 41,83 & $-0,06$ & $-4,78$ \\
\hline
\end{tabular}


*Reflects perceptions of the extent to which public power is exercised for private gain, including both petty and grand forms of corruption, as well as "capture" of the state by elites and private interests.

From the standpoint of personnel security statement as a process of preventing impacts of government authorities on the economy through the regulation of labor relations and the intellectual potential of government authorities, the Control of Corruption indicator points to a low level of personnel security, forasmuch as there are threats of attracting intellectual capital with an insufficient level of professionalism, obtaining benefits from the implementation of personnel policies on the principle of applying political pressure. During the period of implementation of e-government's concept and the democracy principles, this indicator is an identifier of the professionalism and competence of government authorities. Assessing the level of e-government's development and the analyzed WGI for transition economies are tools for identifying personnel security issues in government authorities. The Sustainable Development Goals
"16.5 Substantially reduce corruption and bribery in all their forms", "16.6 Develop effective, accountable and transparent institutions at all levels", "16.7 Ensure responsive, inclusive, participatory and representative decision-making at all levels" are aimed at reducing the level of corruption in countries in all its forms, development of institutions to ensure equity in the judicial system, strengthening the institutional environment, improving the effectiveness of managerial decisions in government authorities. Assessing the achievement of the objectives related to the prerequisites for personnel security is still a challenge, forasmuch as there is no dynamic data on indicators of institution's construction at all levels and strengthening of partnership. The Corruption Assessment indicator of transition economies shows positive shifts in overcoming corruption [14].

Table 4. CSR 16.5.2 Bribery incidence* (\% of firms experiencing at least one bribe payment request) in 2009-2013

\begin{tabular}{|l|c|c|c|}
\hline Country & 2009 & 2013 & Change, $+/-$ \\
\hline Albania & 0,000 & 19,540 & 19,540 \\
\hline Armenia & 15,502 & 7,067 & $-8,435$ \\
\hline Azerbaijan & 52,039 & 15,878 & $-36,161$ \\
\hline Belarus & 15,470 & 8,865 & $-6,605$ \\
\hline Bosnia and Herzegovina & 10,189 & 10,660 & 0,471 \\
\hline Georgia & 9,837 & 2,216 & $-7,621$ \\
\hline Kazakhstan & 32,816 & 26,697 & $-6,119$ \\
\hline Kyrgyzstan & 42,539 & 59,768 & 17,229 \\
\hline Republic of Moldova & 17,794 & 30,954 & 13,160 \\
\hline The Russian Federation & 27,260 & 14,216 & $-13,044$ \\
\hline Serbia & 11,860 & 6,140 & $-5,720$ \\
\hline Ukraine & 38,464 & 50,434 & 11,971 \\
\hline
\end{tabular}

*Proportion of businesses that had at least one contact with a public official and that paid a bribe to a public official, or were asked for a bribe by those public officials during the previous 12 months

In some transition economies (Kazakhstan, Kyrgyzstan, Republic of Moldova, Ukraine) bribery incidence remains a problem in ensuring personnel security.

Table 5. Primary government expenditures as a proportion of original approved budget (\%)* in 20092016

\begin{tabular}{|l|c|c|c|}
\hline \multicolumn{1}{|c|}{ Country } & $\mathbf{2 0 0 9}$ & $\mathbf{2 0 1 6}$ & Change, + /- \\
\hline Albania & 98,71 & 95,91 & 3,46 \\
\hline Armenia & 98,27 & 105,23 & $-0,33$ \\
\hline Azerbaijan & 85,02 & 109,14 & $-41,45$ \\
\hline Belarus & 111,92 & & - \\
\hline Bosnia and Herzegovina & 89,56 & & - \\
\hline Kazakhstan & 96,27 & 111,01 & $-29,46$ \\
\hline Kyrgyzstan & 105,45 & 93,09 & 7,87 \\
\hline Republic of Moldova & 96,12 & 91,76 & - \\
\hline
\end{tabular}




\begin{tabular}{|l|c|c|c|}
\hline The Russian Federation & 107,04 & 101,97 & $-8,19$ \\
\hline Serbia & 99,69 & 93,81 & $-7,59$ \\
\hline Ukraine & 88,43 & 90,74 & $-6,94$ \\
\hline
\end{tabular}

*Develop effective, accountable and transparent institutions at all levels. INDICATOR 16.6.1. Primary government expenditures as a proportion of original approved budget, by sector (or by budget codes or similar)

The regression equation of government efficiency is estimated (see Table 6) depending on the quality of the regulatory environment and the level of corruption control in transition economies with a high level of adequacy (Adjusted R-squared 0.6766); it explains the dependence of the personnel policy and security's effectiveness. With a significance value of $1 \%$, it can be argued that an increase in the quality evaluation of government authorities' regulatory capabilities by 1 point will ensure an increase in the effectiveness of the government of transition economy by 0,4919 points; an increase in the assessment of corruption control by 1 point will increase the effectiveness of the government of transition economy by 0,2908 points.

Table 6. The assessment results of government performance depending on Regulatory Quality and Control of Corruption

Dependent Variable: GOVERNMENT_EFFECTIVNESS

Method: Panel Least Squares

Date: 05/29/20 Time: 21:07

Sample: 19962018

Periods included: 20

Cross-sections included: 12

Total panel (balanced) observations: 240

\begin{tabular}{lllll}
\hline \hline Variable & Coefficient & Std. Error & t-Statistic & Prob. \\
\hline \hline REGULATORY_QUALITY & 0.491881 & 0.032895 & 14.95293 & 0.0000 \\
CONTROL_OF_CORRUPTION & 0.290807 & 0.038599 & 7.534084 & 0.0000 \\
C & -0.108749 & 0.027908 & -3.896711 & 0.0001 \\
\hline \hline Root MSE & 0.206146 & R-squared & 0.679316 \\
Mean dependent var & -0.465302 & Adjusted R-squared & 0.676610 \\
S.D. dependent var & 0.364789 & S.E. of regression & 0.207446 \\
Akaike info criterion & -0.295467 & Sum squared resid & 10.19905 \\
Schwarz criterion & -0.251959 & Log likelihood & 38.45609 \\
Hannan-Quinn criter. & -0.277937 & F-statistic & 251.0223 \\
Durbin-Watson stat & 0.388277 & Prob(F-statistic) & 0.000000 \\
\hline \hline
\end{tabular}

The conducted investigation makes it possible to draw conclusions concerning the basic problems and threats to personnel security in the government authorities of countries with transition economy: corruption, corruption control and the quality of the regulatory environment. Also, personnel security is determined by the level of effectiveness of the company's personnel policy development, professionalism of civil servants, and intellectual capital.

The outlined problems require the development of human resources to ensure effective control of corruption and the quality of the regulatory environment. The availability of basic knowledge in the areas of information security and anti-terrorism security among government officials determines the quality of control and the effectiveness of regulators. In this regard, the need arises to organize and provide conducting majors courses of postgraduate studies to improve personnel's skills through the acquisition of relevant competences in the field of work and general knowledge of antiterrorist security in the profile (including information), increasing the role of legal awareness in everyday life, skills recognition of manipulative technologies.

\section{Discussion}

The problems of ensuring the personnel security of transition economies, identified in the study, correlate with the findings of scientists and confirm the negative impact of corruption, which generates a 
bureaucratic approach to the formation of personnel policy. Countries with low per capita incomes, which are generally characteristic for transition economies, are more prone to corruption [15]. Corruption causes inadequate legal protection and weakness of the institutional system. Anticorruption policy, control of corruption ensures the transition of the country's economy to a market one [16]. Therefore, the effectiveness of personnel policy in transition economies is determined by the ability to combat corruption. It follows herefrom the capacity to develop democracy and e-government. The willingness of the government authorities to serve the interests of society is inversely proportional to the level of corruption in the country [17]. The priority of public interests in the objectives of the government authorities is an obstacle or a protector against corruption, respectively, the level of personnel security increases through the transmission mechanism: from the acquisition of competencies and professional skills to the implementation of effective personnel policy. Excessive bureaucracy hinders effective personnel policy [18]. The high level of personnel security is evidenced by the level of the economy openness, as a consequence of the country's transition to a market economy, and the growth of economic freedom [19]. The institutional mechanism for combating corruption leads to quality institutions and economic freedom, a democratic country; these factors are prerequisites for personnel security [20]. Institutions, culture and personal qualities of the government authorities of transition economies are prerequisites for personnel security [21]. The structure's formality of institutions leads to a decrease in personnel security [22].

\section{Conclusion}

The study conducted makes it possible to draw a number of important conclusions. Personnel security of government authorities refers to theories of personnel management, human resources; it is an important component in ensuring professionalism, development of competencies and skills of personnel in the public administration system. Personnel security is formed as a result of countries' transition to market economic conditions and the transformation of institutions. Personnel policy determines the effectiveness of government authorities. The quality of civil service in transition economies in general and the degree of its independence from political pressure, the quality of public policy development varies significantly in different countries. Internal and external problems of personnel security are at the same time prerequisites for the formation of personnel policy. The quality and independence of institutions affects the quality of management personnel and government authorities. The investigation conducted confirms the low level of personnel security in the government authorities of countries with transition economy. Therefore, threats of attracting intellectual capital with an insufficient level of professionalism emerge; as a result, it contributes to obtaining benefits by the government authorities in the process of implementing personnel policies on the principle of applying political pressure.

\section{References:}

[1] Ismailova, R. Web site accessibility, usability and security: a survey of government web sites in Kyrgyz Republic. Universal Access in the Information Society, 16(1), 2015, pp. 257-264. doi:10.1007/s10209-015-0446-8

[2] Hassan, R. G., Khalifa, O. O. E-Government an

$$
\text { information }
$$

security

perspective. International Journal of Computer Trends and Technology, 36, 2016, pp. 1-9.

[3] Klijn, E. H. Public Management and Governance: a comparison of two paradigms to deal with modern complex problems in D. Levi Faur (ed) The handbook of governance, Oxford: Oxford University Press: 2012, pp. 201-214 Available from: https://www.researchgate.net/publication/2896 52074 New Public Management and Govern ance_A_Comparison [accessed May 27 2020].

[4] Parkhomenko-Kutsevil, O. Personnel security in the system of public governance of Ukraine: theoretical fundamentals, Collection of scientific works. "Efficacy public administration", 37, 2013, pp. 13-20.

[5] Mishchuk I., Zinchenko O. Zinchenko D., Pawliszczy D., Pohrebniak A., Differences in the Assessment of Economic Security of Personnel and Security of Enterprise Staff Interests, WSEAS Transactions on Environment and Development, Vol. 16, 2020, pp. 454-463.

[6] Atikah Nurhayati, Isah Aisyah, Asep K. Supriatna, The Relevance of Socioeconomic Dimensions in Management and Governance of Sea Ranching, WSEAS Transactions on Environment and Development, Vol. 15, 2019, pp. 78-88.

[7] Gilbert, G. R. Human resource management practices to improve quality: A case example of human resource management intervention in 
government. Human Resource Management, 30(2), 1991, pp. 183-198. doi:10.1002/hrm.3930300203

[8] French, E., Goodman, D. An Assessment of the Current and Future State of Human Resource Management at the Local Government Level, Review of Public Personnel Administration, 32(1), 2011, pp. 62 -74. Available from: https://www.researchgate.net/publication/2569 26127_An_Assessment_of_the_Current_and_F uture_State_of_Human_Resource_Managemen $t$ at the Local_Government_Level [accessed May 29 2020].

[9] Kalyayev, A., Efimov, G., Motornyy, V., Dzianyy, R. \& Akimova, L. 'Global Security Governance: Conceptual Approaches and Practical Imperatives,' Proceedings of the 33rd International Business Information Management Association Conference, IBIMA 2019: Education Excellence and Innovation Management through Vision 2020, 10-11 April 2019, Spain, Granada, 2019, pp. 4484-4495.

[10] Kriukov, O. Political and managerial elite as a factor of state personnel security. East Journal Of Security Studies, 4(1), 2019, pp. 5-14. Available from: https://ejss.nuczu.edu.ua/index.php/ejss/article/ view/4

[11] Tykhonova, O. V., et al., Comparative Analysis of Combating Economic Crimes In Ukraine and European Union, International Journal of Management, 11 (3), 2020, pp. 624-632.

[12] Shynkar, T. I., et al., Mechanisms OSF Functioning of Offshore Jurisdictions in the World System, International Journal of Management, 11 (4), 2020, pp. 500-510.

[13] World Bank. Worldwide Governance Indicators. Available from: https://databank.worldbank.org/reports.aspx?Re port_Name $=$ WGI-Table $\&$ Id $=$ ceea $4 \mathrm{~d} 8 \mathrm{~b}$ [accessed May 29 2020].

[14] United Nations. Global SDG Indicators Database. Available from: https://unstats.un.org/sdgs/indicators/database/ [accessed May 29 2020].

[15] Bahoo, S., Alon, I., Paltrinieri, A. Corruption in International Business: A Review and Research Program. International Business Review, 2019. Available from: https://www.sciencedirect.com/science/article/p ii/S0969593119309473 [accessed May 21 2020].
[16] Houston, D. A. Can Corruption Ever Improve an Economy?, Cato Journal, Cato Institute, Vol. 27(3), 2007, pp. 325-342.

[17] Fukuyama, F. What is corruption and how to fight it? Available from: http://www.ridge.uy/wpcontent/uploads/2016/05/Fukuyama_Francis.pd $\mathrm{f}$ [accessed May 21 2020].

[18] Ondo, A. Corruption and Economic Growth: The Case of EMCCA. Theoretical Economics Letters, 7, 2017, pp. 1292-1305. doi: 10.4236/tel.2017.75088

[19] Leite, N., Carvalho Lucio, F. and Ferreira, R. Long-Term Effects of Corruption Control and Economic Freedom on Economic Growth. Theoretical Economics Letters, Vol. 9, 2019, pp. 2965-2974. doi: 10.4236/tel.2019.98183.

[20] Hua, Q. Corruption and economic growth in transition economies. University of Missouri Libraries, Crossref. Web. 2013, doi:10.32469/10355/43141.

[21] Teixeira, A. A. C. Corruption, Economic Growth and Globalization. 2015, doi:10.4324/9781315776828.

[22] De Vaal, A., Ebben, W. Institutions and the Relation between Corruption and Economic Growth. Review of Development Economics, 15(1), 2011, pp. 108-123. doi:10.1111/j.14679361.2010.00596.x

\section{Creative Commons Attribution}

\section{License 4.0 (Attribution 4.0 \\ International , CC BY 4.0)}

This article is published under the terms of the Creative Commons Attribution License 4.0 https://creativecommons.org/licenses/by/4.0/deed.en _US 